\title{
Topical Natural Retinoids
}

\section{The 'Proligand-Non-Ligand' Concept}

\author{
J.-H. Saurat O. Sorg \\ Department of Dermatology, University Hospital, and DHURDV, Geneva, Switzerland
}

Retinoic acid (RA) is widely used for topical therapy of several skin diseases; it also improves the aspect of chronic solar damage. Topical RA induces irritation of the skin, which precludes its use in some skin diseases that respond to systemic retinoids.

Irritation might be explained, in part, by an overload of the RA-dependent pathways with non-physiological amounts of exogenous RA in the skin. The globally attainable concentrations of RA in the different layers from therapeutically efficient formulations have been determined in human skin in vivo. A steep concentration gradient with high concentrations in the epidermis, up to $450 \mathrm{ng} / \mathrm{g}$ wet weight $(1.5 \mu M)$, and relatively low amounts in the dermis $(55 \mathrm{ng} / \mathrm{g}$ wet weight, $180 \mathrm{nM}$ ) is achieved $100 \mathrm{~min}$ following application of RA $0.1 \%$ in isopropanol, corresponding to $15 \%$ of the applied dose of $100 \mathrm{mg}$ [1].

Retinoid content analysis in human skin treated with $0.1 \%$ RA for 4 days under occlusion showed the following values: RA $824 \mathrm{ng} / \mathrm{g}(2,750 \mathrm{nM})$, 13-cis-RA $745 \mathrm{ng} / \mathrm{g}$ $(2,480 \mathrm{n} M)$ and 4-OH-RA $93 \mathrm{ng} / \mathrm{g}$ wet weight $(310 \mathrm{nM})$ [2].

A recent study on percutaneous absorption of RA showed that about $2 \%$ of a single dose of $100 \mathrm{mg}$ in a $0.05 \%$ formulation is absorbed; the same result is obtained after 28 days of daily application [3]. Due to the similarity of chemical structure, a similar pharmacokinetic behaviour is expected for topical 13-cis-RA [4]. Such high tissue concentrations of RA are in overexcess of the concentrations needed to saturate nuclear receptors $[5,6]$.

Although major advances have been made in the analysis of the molecular events resulting from topical application of RA [7], it is still not established if all the therapeutic activities of topical RA are mediated by nuclear receptors, and if irritation is necessary for obtaining some of these activities.

One possibility is that significant biological activity may still be achieved with much lower concentrations of topical $\mathrm{RA}$; in this case, RA is delivered at a low rate from a large epidermal reservoir to its intracellular targets. Alternatively, instead of treating the skin with the ligand of nuclear receptors itself, delivery could be distinctly targeted with 'proligands'.

We have explored the possibility of delivering retinoid activity to human skin topically with a natural retinoid that does not bind nuclear receptors. Such a precursor should be handled by enzymes of keratinocytes in the epidermis and transformed into either RA or storage forms such as alltrans-retinol (ROL) and retinyl esters.

Epidermis is a differentiating, non-homogenous tissue, made of keratinocytes that are not yet committed to terminal differentiation (basal cell layer) and a population of differentiating cells (suprabasal cell layers); the need for, and concentration of, RA may not be identical in all layers and a gradient of RA has been considered to be a key event in the maturation of keratinocytes [8]. This is supported by the fact that the conversion rate of ROL into RA by human keratinocytes depends on the state of keratinocyte differentiation, differentiating keratinocytes being able to oxidise ROL at a higher rate than non-differentiating ones [9]. That enzymes transforming the precursors into RA have distinct activities at different stages of differentiation indicates the possibility of targeting RA to epidermal cells in a differentiation related manner. This would be one approach to reduce side-effects. The use of RA precursors, such as ROL, retinyl esters, all-trans-retinaldehyde (RAL) and $\beta$-carotene, should therefore be considered in this context.

\begin{tabular}{ll}
\hline KARGER & ( 1999 S. Karger AG, Basel \\
Fax +4161306 1234 & 1018-8665/99/1997-0001\$17.50/0 \\
$\begin{array}{l}\text { E-Mail karger@ karger.ch } \\
\text { www.karger.com }\end{array}$ & $\begin{array}{l}\text { Accessible online at: } \\
\text { http://BioMedNet.com/karger }\end{array}$
\end{tabular}

Prof. Jean-Hilaire Saurat

Clinique de Dermatologie, Hôpital Cantonal Universitaire

CH-1211 Genève 14 (Switzerland)

Tel. +41 2237294 22, Fax +41223729460

E-Mail saurat@cmu.unige.ch 
Validation of the concept would imply to demonstrate that: (i) epidermal cells distinctly metabolise the precursor into RA, (ii) topical application of the precursor results in biological effects and (iii) tolerability of the precursor is better than that of RA.

Human keratinocytes transform ROL into RAL and then into RA by two enzymatic steps involving dehydrogenases. The first step is rate limiting and reversible; RAL can be converted enzymatically into either RA or ROL by human keratinocytes, both in vivo $[10,11]$ and in vitro [9]. Epidermal cells have a weak capacity to transform ROL into RAL
$[10,11] . \beta$-Carotene is not converted into retinoids by epidermal cells [Siegenthaler G., unpubl. observations]. We therefore hypothesised that RAL should be an interesting precursor for topical use because: (i) it bypasses the first limiting step of ROL oxidation into RA and (ii) only the epidermal cells capable of RAL oxidation at a pertinent stage of differentiation would generate active ligand(s). In this supplement issue of Dermatology, current knowledge upon RAL has been gathered; most has been presented during a symposium held during the 7th Congress of the European Academy of Dermatology and Venereology in Nice.

\section{References}

1 Schaefer H, Zesch A: Penetration of vitamin A acid into human skin. Acta Derm Venereol Suppl 1975;74:50-55.

2 Duell EA, Åström A, Griffiths CEM, Chambon P, Voorhees JJ: Human skin levels of retinoic acid and cytochrome P-450-derived 4-hydroxyretinoic acid after topical application of retinoic acid in vivo compared to concentrations required to stimulate retinoic acid receptor-mediated transcription in vitro. J Clin Invest 1992;90:1269-1274.

3 Latriano L, Tzimas G, Wong F, Wills RJ: The percutaneous absorption of topically applied tretinoin and its effect on endogenous concentrations of tretinoin and its metabolites after single doses or long-term use. J Am Acad Dermatol 1997;36:S37-S46.
4 Schaefer H: Penetration and percutaneous absorption of topical retinoids. Skin Pharmacol 1993;6(suppl 1):17-23.

5 Crettaz M, Baron A, Siegenthaler G, Hunziker $\mathrm{W}$ : Ligand specificities of recombinant retinoic acid receptors RAR $\alpha$ and RAR $\beta$. Biochem J 1990;272:391-397.

6 Lombardo A, Costa E, Chao WR, Toll L, Hobbs PD, Jong L, Lee MO, Pfahl M, Ely KR, Dawson MI: Recombinant human retinoic acid receptor beta: Binding of synthetic retinoids and transcriptional activation. J Biol Chem 1994;269: 7297-7303.

7 Fisher GJ, Wang ZQ, Datta SC, Varani J, Kang S, Voorhees JJ: Pathophysiology of premature skin aging induced by ultraviolet light. N Engl J Med 1997;337:1419-1428.
8 Darmon M: Retinoic acid in skin and epithelia. Semin Dev Biol 1991;2:219-228.

9 Siegenthaler G, Saurat JH, Ponec M: Retinol and retinal metabolism: Relationship to the state of differentiation of cultured human keratinocytes. Biochem J 1990;268:371-378.

10 Siegenthaler G, Gumowski-Sunek D, Saurat $\mathrm{JH}$ : Metabolism of natural retinoids in psoriatic epidermis. J Invest Dermatol 1990;95:47S$48 \mathrm{~S}$.

11 Siegenthaler G, Saurat JH: Natural retinoids: Metabolism and transport in human epidermal cells; in Saurat JH (ed): Retinoids: 10 Years On. Basel, Karger, 1991, pp 56-68. 